University for Business and Technology in Kosovo

UBT Knowledge Center

UBT International Conference

2017 UBT International Conference

Oct 28th, 9:00 AM - 10:30 AM

\title{
Comparison of quality characteristics of fresh and of dried strawberries
}

Ljubica Karakasova

Ss. Cyril and Methodius University, karakasoval@yahoo.com

Jovanka Ampova

Ss. Cyril and Methodius University

Frosina Babanovska-Milenkovska

Ss. Cyril and Methodius University

Namik Durmishi

University of Tetova

Viktorija Stamatovska

St. Kliment Ohridski University

Follow this and additional works at: https://knowledgecenter.ubt-uni.net/conference

Part of the Food Science Commons

\section{Recommended Citation}

Karakasova, Ljubica; Ampova, Jovanka; Babanovska-Milenkovska, Frosina; Durmishi, Namik; and Stamatovska, Viktorija, "Comparison of quality characteristics of fresh and of dried strawberries" (2017). UBT International Conference. 159.

https://knowledgecenter.ubt-uni.net/conference/2017/all-events/159

This Event is brought to you for free and open access by the Publication and Journals at UBT Knowledge Center. It has been accepted for inclusion in UBT International Conference by an authorized administrator of UBT Knowledge Center. For more information, please contact knowledge.center@ubt-uni.net. 


\title{
Comparison of quality characteristics of fresh and dried strawberries
}

\author{
Ljubica Karakasova ${ }^{1}$, Jovanka Ampova ${ }^{1}$, Frosina Babanovska-Milenkovska ${ }^{1}$, Namik \\ Durmishi $^{2}$, Viktorija Stamatovska ${ }^{3}$ \\ ${ }^{1}$ University of Ss. Cyril and Methodius, Faculty of Agricultural Sciences and \\ Food, Department of Food Processing, R. Macedonia, \\ ${ }^{2}$ Faculty of Food Technology and Nutrition, State University of Tetovo, in Gostivar, Republic \\ of Macedonia \\ ${ }^{3}$ Faculty of Technology and Technical Sciences, University St. Kliment Ohridski - Bitola, in \\ Veles, R. Macedonia \\ karakasoval@yahoo.com
}

\begin{abstract}
The strawberries have a significant place among the berries family. It can be used fresh or for production of different products, available for consumption during the whole year.

The aim of this research is to compare the quality changes of fresh and dried strawberries. The strawberries of variety: elsanta, humi grande and mesecharka, from Skopje region were used for drying. Before drying, the following treatments were applied: $V_{0}$ - not treated, $V_{1}$ - with vitamin $\mathrm{C}, \mathrm{V}_{2}$ - with sugar solution. The drying was performed in Armenian solar dryer. During research the chemical components of fresh and dried strawberries: the total dry matter, the sugars, the total acids, the proteins, the vitamin $\mathrm{C}$ and the mineral matter were examined. On the solar dried strawberry was performed microbiological analysis according to appropriate regulations. Based on the results of this research, the Armenian Solar Dryer showed very good characteristics from the economical and ecological aspect, as well as good quality properties.
\end{abstract}

Keywords: strawberries, quality, solar dryer, treatments.

\section{INTRODUCTION}

Strawberry (Fragaria vesca) is economically important crop, a type of berry fruit. The richness of species and varieties, as well as the diversity in biochemical composition make this fruit very important in the human nutrition [1]. The great interest in this valued culture is not only due to the nutritional value and the excellent taste, but also to the fact that it appears on the market seasonally, during the period when other types of fruit are less present.

As the basic elements of the quality of fruit, that is used in the processing, from a technological point of view are: the pomological properties, the mechanical and the chemical composition. The pomological characteristics such as dimensions, size, shape, color and pericarp of fruits are used not only for assessment of quality, but also are of great importance for the outward appearance, attractiveness and the market value. The mechanical composition is regarding to the weight ratio of the separate parts of the fruit. There are two different parts of the fruit: the useful part and the waste. The basic rule for processing of the fruits is that the amount of waste needs to be as small as possible. The ratio between the useful part and the waste is known as yield. The yield varies depending on the conditions of cultivation, but not on a large scale, because each variety has specific properties and characteristics. Knowledge of the variety and the right choice have a decisive role to play in order to get a quality product [2]. 
According to the research that was done in R. Macedonia from 2002 - 2004 on the mechanical properties of different varieties of strawberries, based on the average weight of the fruit, the examined strawberry varieties were classified into five groups: very large (fruit weight $>14 \mathrm{~g}$ ), large (weight from 9 to $14 \mathrm{~g}$ ), medium ( 7 to $9 \mathrm{~g}$ ), small (5 to $7 \mathrm{~g}$ ) and very small (weight $<5$ g). In this research it was estimated the mechanical composition of the elsanta variety, with the average values for: weight of the fruit $(11.1 \mathrm{~g})$, the height $(30.2 \mathrm{~mm})$, width $(31.6 \mathrm{~mm})$ and thickness $(28.8 \mathrm{~mm})$ [4]. The fruit of the variety humi grande are very large and their weight ranges from 30 to $40 \mathrm{~g}$ [3]. For the variety mesecharka, in $100 \mathrm{~g}$ of fruit, with approximately the same size, there are 95 pieces of fruit. The variety mesecharka bears fruit every month until November.

The chemical composition of the fruit is important both, from the point of view of the diet and from the technological aspect. The chemical composition is regarding to the content of all the ingredients in the product including the water. The components of the chemical composition with their quantity, as well as their interrelations are responsible for formation of the organoleptic, nutritional and biological properties of the product [2]. The quality varieties are considered ones with the highest content of the dry matter, which indicates a higher level of nutrients. The term "dry matter" includes all the nutritional ingredients of the fruit, with the exception of the water [1].

The strawberry has good nutritional value, which depends primarily on the variety, degree of maturity, birthing and applied agro-technological measures [5]. Depending on the variety and growing conditions of the strawberries, the percentage of water is $92 \%$. Besides the water, that is present in high percentage, the strawberries contain sugars, minerals, vitamins, organic acids and antioxidants, which are necessary for the normal functioning of the human body [6]. The percentage of water in the strawberries is from 82 to $88 \%$, total dry matter from 9 to $12 \%$, total sugars from 4 to $13 \%$, reductive sugars from 4 to $10 \%$, sucrose from 0.2 to $2 \%$, total acids from 0.6 to $1.5 \%$, mineral matter from 0.3 to $1 \%$, pectic matter from 0.5 to $1.5 \%$, tannins in trace and vitamin $\mathrm{C}$ from 20 to $28 \mathrm{mg} / 100 \mathrm{~g}$ [3]. According to the other research, the strawberries contain: $3.8 \%$ invert sugar, $1.7 \%$ sucrose, $4.5 \%$ to $7.8 \%$ total sugars, total acidity $0.50 \%$ and $\mathrm{pH}$ 3.5. [2]. Some authors indicated that in the chemical composition of the strawberries there are: $8.3 \%$ carbohydrate, $0.8 \%$ protein, fat $0.5 \%$, ash $0.5 \%$ and water $89.9 \%$ [7]. The strawberry is considered to be a rich source of minerals, which gives it a special value.

Drying is one of the oldest methods of preserving fruits and is an excellent method for preserving the flavor and the nutrients. Fruit preservation by drying allows the fruit to be used throughout the year, which is crucial and necessary for good human health, especially in those months of the year when the fruit supply is reduced or not present at all on our markets [8]. The fruit can be dried in different ways, depending on the possibilities, ie the equipment, as well as the chemical and physical properties of the fresh product [2]. Which technological procedure will be applied, which reactions can be expected during the processing, what product and how much quantities will be obtained depends on the chemical composition and the technological properties of the raw material. Through the development of technology and finding different techniques, the use of solar energy in the solar dryer has found an increasingly greater application and utilization. The technology of drying fruits in solar dryers is the cheapest way of drying, since is uses the free solar energy [1]. It has been established that the main factors affecting the efficiency of drying are the air, the temperature, the humidity and the fast movement of the air [9]. There are three types of solar dryers present in Macedonia: the Armenian type, the German type Hohenheim and the Macedonian type, whiuch are point to the great benefit and effect of the application of the solar energy and the solar dryers [10],

Dried fruit is a product obtained by drying the fresh and technologically mature fruit - whole or cut in pieces, following an appropriate procedure in order to become suitable for longer storage. The dried fruit should meet the following conditions: to have flavor and color inherent in the variety; by immersing in boiling water for 10 minutes, to show good ability for rehydration; after the rehydration to get the smell and taste of the fruit from which it is produced; not to have stains 
that occurred as a result of physiological damage of the fruit, from burning, etc.; not to have a smell and a taste of overdried (burned) fruit, nor any other foreign smell and taste; not to be polluted by mechanical or biological impurities and not to contain insects in any stage of their evolution [11].

\section{MATERIALS AND METHODS}

For performing the examinations in this research, were used fruit berries of the strawberry varieties: elsanta, hummi grande and mesecharka. The fruit was grown in a hanging system in greenhouses. The fruits were harvested in technological maturity. After a visual assessment on the field, for estimating the moment of harvesting, the samples were taken for the analysis of the mechanical and chemical composition of the fruit.

The variety elsanta (Elsanta) is of Dutch origin, created by hybridization of the strawberry varieties gorella and holiday. The fruit is flattened, elongated to round, quite large, with a red and shiny surface. The mesocarp of the fruit is reddish orange, with excellent organoleptic properties, good hardness consistency, juicy and tasty. The fruit is suitable for fresh usage, but also for processing [12].

The variety hummi grande (Hummi Grande) originates from West Germany and is characterized by a large berries fruit. The fruit, on the sun-exposed side is bright red, while on the bottom side has pink to pale red color. The mesocarp is characterized by medium hardness and juiciness, with a sweet-sour taste and moderate aroma [13].

The variety mesecharka (Fragola Quatro Stagioni) originates from Italy, obtained by selection of remontant types of wild strawberry (F. Vesca var. semperflorens) from the Alps. The fruit of the varieties mesecharka is reddish, on the intersection the mesocarp of the fruit is with a creamwhite color, with a sour taste and a strong aroma.

From each variety of strawberries were measured 20 berries fruits. Thereby were measured the weight of the useful part and the waste of the strawberry fruit. The weight of the fruit was determined by measuring on the "Mettler" analytical balance, with an accuracy of $\pm 0.01 \mathrm{~g}$. The yield was calculated mathematically, expressed in percentage. The height, the width and the thickness of the fruit were measured by vernier caliper (subler) with an accuracy of $\pm 0.1 \mathrm{~mm}$.

Using the laboratory standard methods, the following chemical parameters were determined in the strawberries: total dry matter, total sugars, sucrose, glucose, fructose, total acids as citric acid, vitamin $\mathrm{C}$, proteins and mineral matters (total ash) [11].

-The total dry matter was determined by gravimetric method, in the oven dryer at $105^{\circ} \mathrm{C}$, up to constant mass;

-Determination of the sugars, sucrose, glucose and fructose by applying liquid chromatography, HPLC-method with RI-detector;

-The total acids were determined by a volumetric method, with a $0.1 \mathrm{M} \mathrm{NaOH}$ solution and an indicator of $1 \%$ phenolphthalein solution, expressed as citric acid;

-The proteins were determined through the content of nitrogen, analyzed with the Kjeldahl method;

-The vitamin $\mathrm{C}$ was determined according to the Tillmans method;

-The mineral matter (total ash) was determined by a gravimetric method, by incineration and burning of samples in a Muffle oven, at a temperature of $525 \pm 25^{\circ} \mathrm{C}$;

Technological procedure for production of dried strawberries

During the process of drying, by the evaporation of the free water, the weight and the volume of the fruits decreases, and the amount of dry matter increases, which increases the concentration of sugars, acids and other ingredients, and at the same time the development of microorganisms becomes disabled. For a good quality of the final product, it is necessary to use a quality raw material. The fruit should be healthy, harvested in a phase of uniform technological maturity, 
without mechanical, physiological and phytopathological damages. The strawberries were harvested manually (one by one) and placed in clean, dry, wooden packaging. After receiving the raw material, the technological process of drying strawberries begins.

The technological procedure for drying strawberries was performed through the following operations: selecting, washing, removing the unsuitable part, re-controlling and pretreating, cutting the fruits in halves and placing the fruits for drying, drying, cooling, packaging and storage. Washing is a technological operation that is mandatory in every fruit processing. Although the strawberry fruit that was subject to this examination were grown on a substrate, in greenhouses and they did not have direct contact with the soil, before being set for drying, they were washed, under a tap with low jet of water, due to their sensitive consistency. The washed fruit is placed in a strainer, after which are removing the stalk. Then was performed the inspection and selection according to the required standards, and the fruits were exposed to a pretreatment, where it was placed in one of the three variants: $\mathrm{V}_{0}$ variant - (control) without any treatment; $\mathrm{V}_{1}$ variant - the treatment with a $2 \%$ solution of ascorbic acid on each of the varieties of strawberries, elsanta, hummi grande and mesecharka, for a period of $5 \mathrm{~min}$.; $\mathrm{V}_{2}$ variant - the treatment with a sugar solution (2:1) on each of the varieties of strawberries, elsanta, hummi grande and mesecharka, for a period of $5 \mathrm{~min}$. The treated fruits were cut into halves and then placed on wooden drying shelves, with plasticized grids, with an area of $1 \mathrm{~m}^{2}$.

In our examination, for the drying was used the Armenian solar dryer, which is walled on the north side, and on the south side it is covered with glass set at an angle, through which the sun's rays penetrate (Figure 1). At the ground floor there are intake openings for fresh air, and in the upper part there are exhaust openings (ventilators) for the wet and hot air. On the bottom, there is a layer of gravel or stones from $2 \mathrm{~cm}$ to $3 \mathrm{~cm}$, dark colored, naturally or artificial. They absorb the heat, which increases the air temperature, and the drying of the fruit is accelerated. In the evening the intake openings are closed, and the intake openings in the gravel zone are opened. The air that passes through the heated stones enters in the dryer enabling the drying process to continue at night, but with a lower intensity. The temperature in our conditions was reaching from 65 to $70{ }^{\circ} \mathrm{C}$ during the day, and from 30 to $40{ }^{\circ} \mathrm{C}$ during the night, which favorably reflected on the drying of strawberries, both during the day and in the night. Factors that significantly affect the evaporation of the water from the fruit are: the temperature, the humidity and the airflow [1].

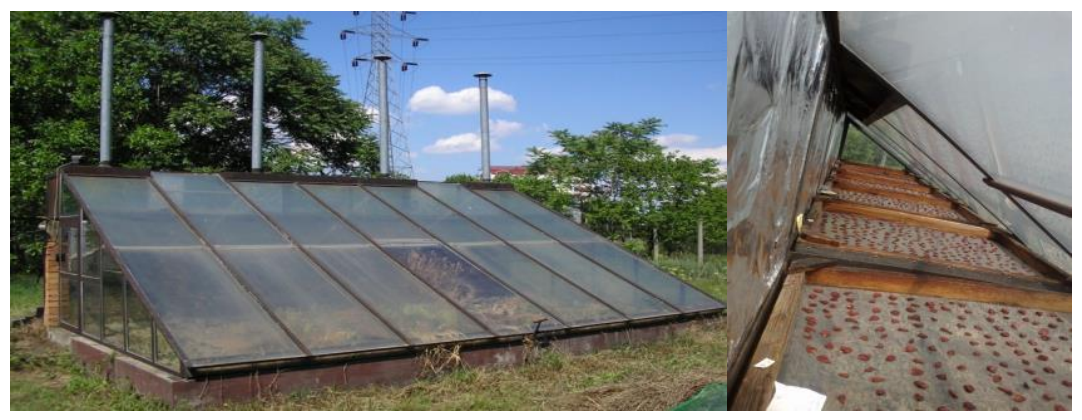

Figure 1. The Armenian solar dryer

The prepared strawberrie of the mesecharka variety were set for drying on May 10, 2012, and the drying process lasted for three days, at an average outdoor temperature of $17.9^{\circ} \mathrm{C}$ during the period of the drying process, and the average humidity was $62.86 \%$. The solar drying of the varieties of elsant and hummi grande lasted for five days, starting from 10. 05. 2012 to 15. 05. 2012 , with an average outdoor air temperature of $15.6^{\circ} \mathrm{C}$ and with an average humidity of 68.77 $\%$. The average temperature during the month of May, when drying was performed for the strawberries: elsanta, hummi grande and mesecharka, was $16^{\circ} \mathrm{C}$, with the average air humidity 
of $67.92 \%$. For uniform drying of whole or cut strawberries, they were flipped over for the duration of the drying process. The dried strawberries, in order to be successfully preserved for a longer period of time, need to be packaged in appropriate packaging and stored in suitable storage conditions, protected from moisture and direct sunlight.

\section{RESULTS AND DISCUSSION}

In the research there were included the strawberry varieties: elsantana, hummi grande and mesecharka. The size and the weight of the fruit are of great importance not only for the outer appearance, but also for the yield and the quality of the fruit [1].

Pomological properties of the strawberry fruit

From the obtained results, it can be concluded that with the highest average values in terms of the height $(35.7 \pm 1.06 \mathrm{~mm})$, the width $(29.05 \pm 0.67 \mathrm{~mm})$ and the thickness $(29.47 \pm 1.39 \mathrm{~mm})$ was caracterized the fruit of the variety elsanta. Then follows the fruit from the variety hummi grande, with the height of $31.26 \pm 1.19 \mathrm{~mm}$, the width $(26.11 \pm 0.79 \mathrm{~mm})$ and the thickness $(28.35 \pm 0.82 \mathrm{~mm})$, and the lowest values were estimated in the strawberries of mesecharka with the height of $18.03 \pm 0.44 \mathrm{~mm}$, the width $12.83 \pm 0.33 \mathrm{~mm}$ and the thickness of $13.76 \pm 0.27 \mathrm{~mm}$. According to the determined data on the average weight of the strawberry fruit in the examined varieties, elsanta, hummi grande and mesecharka, were classified in the following groups. The fruit of the variety mesecharka, with an average weight of $1.40 \pm 0.07 \mathrm{~g}$ belongs to a group of very small fruit (weight $<5$ ), the fruits of the hummi grande, with an average weight of 11.29 $\pm 0.94 \mathrm{~g}$ belongs to a group of large fruit (weight from 9 to $14 \mathrm{~g}$ ) and the fruits of the elsanta variety, with an average weight of $14.38 \pm 0.94 \mathrm{~g}$ belongs to the group of very large fruits (with a weight of $>14 \mathrm{~g}$ ).

By analyzing the variance, in terms of the weight, the height, the width and the thickness of the strawberries, it was determined a statistically significant difference between the strawberries from the varieties elsanta and mesecharka and between the varieties hummi grande and mesecharka, with determined values of $\mathrm{LSD}_{\text {weight }}=11.48, \mathrm{LSD}_{\text {height }}=9.64, \mathrm{LSD}_{\text {width }}=8.25, \mathrm{LSD}_{\text {thickness }}=$ 11.01 , at a probability level of $\mathrm{p}=0.01$.

The strawberries of the mesecharka varieties, were harvested without leaves, actually without waste, but $100 \%$ fruit utilization, which is not the case with the other two varieties of strawberries. For other two varieties of strawberries, it was estimated that the elsanta has a yield of $97.69 \%$, and the hummi grande $97.49 \%$ yield. According to this, it was concluded that for the fruit of the strawberry varieties: elsanta, hummi grande and mesecharka, there was a high degree of utilization.

Chemical composition of the strawberry fruit

According to the obtained results of the research, for the content of the total dry matter in the varieties of strawberry elsanta, hummi grande and mesecharka, it was concluded that with the highest content of total dry matter $14.43 \%$ were the strawberries of the variety mesecharka, and with the smallest value of $9.33 \%$ were characterized the strawberries of the variety hummi grande. For the variety elsanta, the content of total dry matter was $10.77 \%$. The content of the total dry matter in the strawberries varieties, for elsanta $(10.77 \%)$ and for hummi grande $(9.33$ $\%$ ) were within the limits of the previos examinations from other authors, from $9.08 \%$ to 11.9 $\%$, or from $9 \%$ to $12 \%$ [5], [14].

Sugars, together with acids, are the basic ingredient for the formation of the taste of the fruit. The content of the total sugars varies, depending on the variety, degree of maturity and cultivation conditions. The content of total sugars in the strawberries of the variety elsanta was with the highest values of $7.62 \%$, then in the variety mesecharka was $6.34 \%$, and in the variety hummi grande was $5.10 \%$. According to the previous studies, the content of the total sugars in the strawberries fruit was in the ranges of $4.5 \%$ to $7.8 \%$ [2]. The most common sugars in the strawberry are sucrose, glucose and fructose. According to the analyzes of the sugar content in 
the fruits of the examined strawberry varieties, elsanta, hummi grande and mesecharka, the highest value for sucrose $\quad(1.87 \%)$, glucose $(2.87 \%)$ and fructose $(2.88 \%)$ were determined in the strawberry variety elsanta and the lowest value were in the fruits of the variety hummi grande, $1.10 \%$ for sucrose, $2.00 \%$ glucose and $2.00 \%$ fructose. In the strawberries of the variety mesecharka, the values were: for sucrose $1.34 \%$, fructose $2.5 \%$ and glucose $2.5 \%$. According to the other research, in the strawberry of the variety elsanta, the content of sucrose was from $1.12 \%$ to $1.29 \%[15]$

The most common acids in the fruit are citric, malic and tartaric acid, which are known as "fruit acids". In the last phase of the fruit maturation, the content of acids decreases, while the content of sugars increases. According to the research, the highest value for total organic acids of $1.26 \%$ was determined in the strawberries of the variety mesecharka, and the lowest value of $0.90 \%$ was determined in the variety elsanta. In the strawberries of the variety hummi grande, the content of total organic acids was $0.92 \%$. In the research done by another author, the content of total acids in strawberries amounted to $1.00 \%$ [11]. For the variety elsanta, according to a previous research, it was determined a content of total acid of $0.84 \%$, while according to others, this values were within the range from $0.98 \%$ to $1.20 \%$ [4], [15].

Strawberries are a good source of vitamin $\mathrm{C}$, which is a strong natural antioxidant, soluble in water, but very sensitive, quickly degradeble under the exposure of light, air and high temperature (thermolabile). Because of these features, the strawberries need to be processed as soon as possible after their harvest. From the obtained results, the highest value of the vitamin C (106.57 $\mathrm{mg} / 100 \mathrm{~g}$ ) was determined in the strawberries of the variety hummi grande, the vitamin $\mathrm{C}$ content in the strawberry elsanta was $69.33 \mathrm{mg} / 100 \mathrm{~g}$ and the lowest value of the vitamin C was obtained in the fruits of the variety mesecharka $(44.96 \mathrm{mg} / 100 \mathrm{~g})$. Some prior findings suggest that the content of vitamin $\mathrm{C}$ in the strawberries, was $50,00 \mathrm{mg} / 100 \mathrm{~g}$ or $83.6 \mathrm{mg} / 100 \mathrm{~g}$ for the elsanta variety [11], [16]. In the previous research in R. Macedonia, were made examination on 17 varieties of strawberries, and it has been established that the content of vitamin $\mathrm{C}$ in average was $87.90 \mathrm{mg} / 100 \mathrm{~g}$. For the elsanta variety, which was also the subject of analysis and in our research, the content of vitamin C was $98.81 \mathrm{mg} / 100 \mathrm{~g}$ [4].

The results of the performed analyzes for protein show that the highest value was determined in the variety mesecharka (7.09\%), in the variety elsanta the value was $3.68 \%$ and the lowest value for protein was determined in the fruits of the variety hummi grande $(2.10 \%)$. The protein content in strawberries, according to other analysis was $0.40 \%$ [11].

The mineral matters, compared to the other matters in the fruit, are stable and do not change during the preservation technology and storage. According to the analysis of the content of mineral matter (total ash) in the examined strawberries varieties, with the highest value of 0.51 $\%$ were the strawberries of the variety mesecharka and with the lowest value of $0.20 \%$ was the variety hummi grande. In other research it was found that the total ash content in the strawberry fruit was $0.5 \%$ or the total ash content was in the range of $0.3 \%$ to $1.0 \%$ [11], [3].

Chemical composition of dried strawberry fruit

After the drying was completed, the analysis was made of the dried fruit for determining the contents of the following parameters: total dry matter; total sugars, sucrose; glucose; fructose; total acids expressed as citric acid; vitamin C; proteins and total ash.

According to the obtained results for the content of total dry matter in the dried strawberries of the varieties: elsanta, hummi grande and mesecharka, it was estimated that with the highest average value was the dried fruit of the mesecharka ( $83.30 \%)$, and with the lowest value was the dried fruit of the elsanta variety $(80.72 \%)$. For the elsanta variety, the highest value $(82.35 \%)$ of total dry matter was determined in the control variant $\mathrm{V}_{0}$, and the lowest value (79.06\%) was in variant $\mathrm{V}_{2}$. The variety hummi grande was characterized by the highest value of total dry matter $(81.41 \%)$ in variant $V_{1}$, and the lowest value of $80.78 \%$ was determined for the variant $V_{2}$. In the strawberries of the variety mesecharka, the value of the total dry matter was highest (84.05 $\%$ ), in the variant $\mathrm{V}_{1}$, and the lowest $(82.71 \%)$ in the control $\mathrm{V}_{0}$ variant. 
In terms of the total sugars content, the highest average value of $28.45 \%$ (with $0.30 \%$ sucrose, $13.77 \%$ glucose and $14.38 \%$ fructose) was determined in the elsanta variety, while the lowest average value of $21.78 \%$ (with $0.88 \%$ sucrose, $10.32 \%$ glucose and $10.58 \%$ fructose) had the fruit of mesecharka variety. Based of the obtained results, it was estimated that the lowest content of total sugars, $15.08 \%$ (with $0.69 \%$ sucrose, $6.76 \%$ glucose and $7.63 \%$ fructose) was in the strawberries of the variety mesecharka, in the variant $\mathrm{V}_{1}$, while the highest content of total sugars was $34.61 \%$ (with $0.64 \%$ sucrose, $16.16 \%$ glucose and $17.81 \%$ fructose) was determined in the variety hummi grande, in the variant $\mathrm{V}_{1}$.

The average value for the total acid content expressed as citric acid, ranged from $1.03 \%$ in the variety mesecharka, as the lowest value, up to $1.14 \%$ as the highest average value in the elsanta variety. It was estimated that the control variant $\mathrm{V}_{0}$ of the variety hummi grande had the highest value of $1.23 \%$ for the content of total acids, while for the same variety the lowest value was $0.98 \%$ in the variant $\mathrm{V}_{1}$.

The highest average value of $115.25 \mathrm{mg} / 100 \mathrm{~g}$ of vitamin $\mathrm{C}$ was determined in the variety hummi grande, while the lowest average value of $65.68 \mathrm{mg} / 100 \mathrm{~g}$ was estimated for the variety mesecharka. The control variant $\mathrm{V}_{0}$ for the strawberries of the veriety mesecharka, was characterized by the lowest value of $32.79 \mathrm{mg} / 100 \mathrm{~g}$ of vitamin $\mathrm{C}$ content, and the highest value of $132.74 \mathrm{mg} / 100 \mathrm{~g}$, was determined in the variant $\mathrm{V}_{1}$, of the variety hummi grande.

The highest average value of $8.46 \%$ for protein content was determined in the fruits of the variety mesecarka, while the lowest average value of $2.63 \%$ was found in the fruit of the variety hummi grande. Regarding the treatments, the lowest protein content of $1.92 \%$ was determined in the control variant $\mathrm{V}_{0}$ of the hummi grande variety, and the highest content of protein (8.84\%) had the strawberries of the mesecharka variaty, in the variant $\mathrm{V}_{2}$.

The highest average value of $5.19 \%$ for total ash content was estimated in the variety mesecharka, while the lowest value (4.34\%), was determined in the fruits of the variety elsanata. In the variety elesanta, the variant $\mathrm{V}_{2}$, was determined the lowest value $(3.80 \%)$ for the total ash content, and the highest value of $5.54 \%$ was determined in the control variant $\mathrm{V}_{0}$ of the variety hummi grande.

The yield in production varies by varieties and has a great economic and technological significance in the processing of all agricultural products. From the obtained results, it was estimated that in order to obtain a $1 \mathrm{~kg}$ of dried strawberries, it takes in average $9.07 \mathrm{~kg}$ fresh fruit of the variety elsanta, $10.08 \mathrm{~kg}$ of the variety hummi grande, and $7.24 \mathrm{~kg}$ of the mesecharka variety.

\section{CONCLUSION}

According to the results of the analysis of fresh and dried strawberries, we can conclude the following:

-With the highest average values in terms of the height, the width and the thickness were caracterized the fruits of the variety elsanta, and the lowest values for these parameters were estimated in the variety mesecharka.

-The fruit of the variety mesecharka, belongs to the group of very small fruit, the variety hummi grande, belongs to the group of large fruit and the elsanta variety belongs to the group of very large fruit.

-In terms of the weight, the height, the width and the thickness of the strawberries, it was determined a statistically significant difference between the varieties elsanta and mesecharka and between the varieties hummi grande and mesecharka.

-Regarding the yield, all varieties of strawberries have a high degree of utilization.

-For the chemical composition of the fresh strawberries, the elsanta variety has the highest value for: total sugars; the hummi grande variety was characterized by the highest value of vitamin $\mathrm{C}$, 
and the highest values for the variety mesecharka were determined for: total dry matter, total acids, total ash and protein.

-For the chemical composition of the dried strawberries, the highest average values were determined in the variety elsanta for total sugars and total acids; in the variety of hummi grande for vitamin $\mathrm{C}$; and in the variety mesecharka for the total dry matter, protein and total ash.

-For the variety elsanta, the control variant $\mathrm{V}_{0}$ was characterized by the highest values of the total dry matter; for the variant $\mathrm{V}_{1}$ the highest values were determined for the proteins, total acid, total ash and the vitamin $\mathrm{C}$; in the variant $\mathrm{V}_{2}$, the highest value was determined for total sugars.

-For the variety hummi grande, the control variant $\mathrm{V}_{0}$ was characterized by the highest values for the total acids and total ash; in the variant $\mathrm{V}_{1}$ was determined the highest values for the total dry matter, total sugars, proteins and vitamin $\mathrm{C}$.

-For the variety mesecharka, for the variant $\mathrm{V}_{1}$, were determined the highest values of the total dry matter, total acids, total ash and the vitamin $C$; in the variant $V_{2}$ the highest values were estimated for total sugars and proteins.

-According to the yield in production was estimated, that to obtain $1 \mathrm{~kg}$ of dried strawberries, required: $9.07 \mathrm{~kg}$ fresh fruit of the variety elsanta, $10.08 \mathrm{~kg}$ of the variety hummi grande, and $7.24 \mathrm{~kg}$ of the mesecharka variety.

-With the best mechanical and pomological properties was characterized the strawberry from the elsanta variety, and the variety mesecharka was with the best chemical properties.

-With the applied treatment of the strawberries for the three varieties, in the variant $V_{1}$ and the variant $\mathrm{V}_{2}$ was noted that some of the soluble constituents were lost in the water, especially in the varieties elsanta and hummi grande.

-In the solar drying of strawberries, consideration should be given to the choice of the raw material, the variety, the degree of maturity of the fruits and the weather conditions during the drying period. The drying in the Armenian dryer was shown to be evenly and uniform.

\section{REFERENCES}

1. аракашова Љ. (2003). Соларно сушење на кајсии, Докторска дисертација, Скопје 1211.

2. [2] Niketić - Aleksić G. (1994). Tehnologija voća i povćra III izdanje, Poljoprivredni fakultet, Beograd-Zemun,, 425,149-151.

3. Velićković M. (2000). Gajanje jagode i maline,Zemun, 147; 9-22;

4. Поповски Б. (2008). Биолошки и производни карактеристики на накои перспективни сорти јагоди, Докторска дисертација,Универзитет „Св. Кирил и Методиј“ Скопје, Факултет за Земјоделски науки и храна - Скопје, 218.

5. Пауновић С., Мишић П., Станчевић А., (1974). Јагодасто воче - јагода, малина, црна рибизла, купина), Београд ,354,11-21.

6. Благојевић Р, Божић В.(2012). Технологија производње јагоде, 54; 5-7, 21

7. Katalinić V. (2006). Kemija mediteranskog voća i tehnologija prerade, Kemijskotehnološkog fakultet, Split,97, 2-22.

8. Deak S., Füstös Zs.(2009). Shelf life and storage of strawberry varieties, Original scientific paper, University of Szent Istvan, Central Agricultural Office,Directorate of Plant Production and Horticulture Variety Testing, Skladištenje I oćuvanje svežine sorti jagoda -originalni naućni rad, p.229-231; 
9. Сиваков Л., Каракашова Љ. (2007). Преработка на зеленчук и овошје,ФЗНХ, Скопје, 195.

10. Каракашова Љ., Сиваков Л., Ристевски Б., (1999), Соларно сушење на овошје, Зборник на трудови XXIV, средба Факултет - Стопанство, Земјоделски факултет, Скопје, 217 - 221

11. Vračar LJ. (2001). Prirućnik za kontrolu kvaliteta i svežeg i prerađenog voća, povrća i pećurki i osvežavajućih bezalkoholnih pića, Novi Sad, 2001, 220; 20, 48-53;

12. Кипријановски М (2003). Прирачник за одгледување на јагоди, Car International Macedonija, Скопје, 72, 4-15.;

13. Станчевић А. (2002). Практично воћарство, Београд, 278, 112-114.

14. Velićković M.(2002). Voćarstvo,Beograd, 337, 271 - 272.

15. Milivojević J., Nikolić M., Oparnica M. (2005/2006). Uticaj optičkih osobina malč folija na pomološke osobine novointrodukovanija sorti jagode (Fragaria ananassa Duch.), originalni naučni rad, Beograd,

16. Nikolić M., Milivojević J., Nikolić Č. (2007). Rodnost i kvalitet ploda sorte jagode „Elsanta“ vertikalnom sistemu uzgoja, originalni naučni rad, Zemun 